sciendo

Book Review

Protágoras, de Platão.

Tradução, introdução e notas de Ana da Piedade Elias Pinheiro Lisboa

José Trindade Santos

Universidade de Lisboa

Disputatio No. 8

November 2000

DOI: $10.2478 /$ disp-2000-0012

ISSN: 0873-626X 
Por fim, cabe ressaltar um ponto, a respeito da leitura das idéias do Círculo de Viena, por parte da posteridade. Haller tem razão quando, ao longo do seu livro, aponta para várias teses de neopositivistas que cairiam no esquecimento e que só seriam retomadas por outros autores, décadas depois. Não obstante, ele esquece-se de que os próprios neopositivistas possibilitaram o olvido dos seus méritos, na medida em que muito enfatizaram a recusa da metafísica, sendo, porém, bastante discretos no tratamento de questões como a falibilidade do conhecimento científico, por exemplo. Não se pode estranhar que a posteridade tenha voltado sua atenção para um item sobre o qual os neopositivistas (Neurath, em particular) gastaram tinta em grandes proporções.

Estas observações críticas não devem atingir o valor do livro de Haller. O texto é bom, claro e de agradável leitura. Merece tradução para outras línguas, de modo a tornar-se acessível a um maior número de leitores.

\section{Nelson Gonçalves Gomes}

Departamento de Filosofia

Universidade de Brasília - ICC Ala Norte

Campus Universitário Darcy Ribeiro

Caixa Postal: 04661

Brasília - DF - Brasil

gomes@unb.br

Protágoras, de Platão. Tradução, introdução e notas de Ana da Piedade Elias Pinheiro Lisboa. Lisboa: Relógio D’Água, 1999, 185 pp.

A edição da primeira tradução portuguesa do Protágoras, feita a partir do original grego, constitui um acontecimento relevante no panorama filosófico e cultural. A qualidade do trabalho apresentado - adianto já - permite saudar com alegria esta tão desejada publicação. Mas começarei por apresentar uma interpretação do argumento, para depois passar à apreciação da obra.

1. O Protágoras é um dos diálogos platónicos mais brilhantes e simultaneamente que maior perplexidade causa ao leitor. Este "Congresso dos sofistas», na feliz designação de E. R. Dodds, reúne na mesma sala quatro grandes figuras da cultura grega clássica: de um lado, os sofistas Hípias, Pródico e Protágoras, do outro, Sócrates e um punhado de outros atenienses notáveis. O debate opõe o filósofo ao sofista que Platão escolheu como personagem epónima da obra, mas nunca perde o contacto com os outros circunstantes. Discute-se, em geral, o valor do ensino sofístico e, em particular, o daquele que Protágoras veio a Atenas oferecer, centrado na virtude política. 
Sócrates afronta o opositor no seu estilo habitual. Começa por Ihe perguntar «que benefício obterá» um discípulo do seu ensinamento (318a), para o pressionar a esclarecer a natureza e objectivos desse ensino (318b sqq).

Está assim lançado o debate, que vertiginosamente se desloca através de uma cadeia de questões: 1) ensino da virtude; 2) unidade da virtude; 3) causação e auto-predicação da virtude; 4) identidade e contrariedade nas «partes» da virtude; 5) aquisição e conservação da virtude (ensaio de exegese poética); 6) a coragem; 7) a akrasia; 8) coragem e cobardia; 9) epílogo: inversão das posições iniciais sobre a possibilidade de ensino da virtude; 10) conclusão.

Tudo isto, em pouco mais de 50 páginas de Stephanus, a acrescentar a uma dupla introdução, um mito - que vale por si só como documento sobre a identidade cultural grega -, mais duas ou três digressões, interlúdios dramáticos e cenas de conjunto, dá prova de um virtuosismo literário único. Mas deixa dúvidas sobre a unidade e o alcance filosófico da obra. Exactamente onde quer Platão chegar? Há alguma concepção de virtude que queira transmitir, ou aspira tão-só a refutar Protágoras? Como se não bastasse, a «ironia socrática» (neste caso mais platónica) atinge limites que violam o bom senso: quem se lembraria de afirmar que na Lacedemónia «há o maior número de sábios da Terra» (342a-b)?

Tenho de ir por partes. A questão nuclear do diálogo - todas as outras a reflectem - é a do ensino da virtude. Protágoras acha que é possível ensiná-la e que é isso que ele faz. Mas a sua posição é delicada. Se só o saber se ensina e a virtude é saber - esse é o único ponto em que os dois contendores convergem (361a-b; para Protágoras, vide 318b, 318d-319a, 330a, 352c-d, 357c, d) -, ela é ensinável. O sofista defende, contudo, que a coragem, distinta das outras virtudes, não é saber. Daí resulta uma concepção funcionalista da virtude, aos olhos de Sócrates, dificilmente ensinável.

Para o provar, arma contra ela um complexo dispositivo dialéctico. Com a questão da unidade da virtude pretende levar Protágoras a assumir uma de duas posições: ou a virtude é una, é saber e, portanto, se ensina; ou a virtude não é una e não pode, toda ela, ser saber, logo não é ensinável. Esta é a «armação» que suporta o elenchos. E não é por o diálogo a não a explicar que ela não será evidente a Protágoras. Como se justifica então a sua opção?

É fácil ver que, se optasse pela primeira alternativa, a sua posição seria insustentável: como se pode ensinar TODA a virtude? É esse o significado oculto da reserva inicial de Sócrates $(319 a-b)$ quanto à possibilidade de um ensino - tradicional e não filosófico - da virtude. É, portanto, natural que o sofista rejeite essa possibilidade.

Mas a outra alternativa vai conduzi-lo a não menores dificuldades. Por um lado, há relações de identidade a ligarem as virtudes e a oporem-nas aos 
vícios decorrentes da sua falta, por exemplo, o saber. É ele extensível a toda a virtude?

Ora Protágoras, manifestando embora o maior respeito pelo saber, sustentará que, nesse domínio, a coragem se distingue das outras virtudes (349d: há ignorantes e loucos corajosos). Por outro lado, nos planos dramático e metodológico, não tarda a rebentar o conflito entre os estilos dos dois opositores: Sócrates prefere a dialéctica, Protágoras, o virtuosismo no discurso.

Da sobreposição destas duas linhas resultam os confrontos e os amuos, que ameaçam pôr cobro ao debate. De início, o sofista declara-se pronto a aceitar as imposições de Sócrates, mas não tarda a manifestar desagrado (332a), “concorda contrafeito» (333b), e «acha-se exasperado (333e), começando, a partir de $334 d$ - com toda a razão, creio - , a opor-se às exigências de Sócrates.

Aparentando aceitar os protestos do sofista, Sócrates abandona momentaneamente a posição de condutor do elenchos, condescendendo numa digressão, dedicada à exegese de um fragmento de Simónides. Mas acaba por obter nesse domínio uma vitória tão retumbante que anula toda a resistência da parte do sofista, forçando-o a regressar ao debate, movido pela vergonha $(348 b-c)$.

Não é fácil integrar esta digressão no argumento do diálogo. Antes de mais, o tema é ainda o da aquisição e conservação da virtude. Com a sua intervenção, Sócrates demonstra dois pontos relevantes: primeiro, estabelece a diferença entre "ser» e «tornar-se» virtuoso, sublinhando que só aos deuses caberá o «privilégio» (geras; melhor que a opção da tradutora: "dádiva») de uma natureza virtuosa; segundo, acena ironicamente ao relativismo de Protágoras (334a-c), mostrando a condição mista da natureza humana (346c-347a).

Logo a seguir a um breve interlúdio que assinala o fim da digressão, o debate é resumido $(349 b-c)$ e retomado. É agora nítida a diferença que distingue a coragem das outras virtudes (349d). Sócrates regressa à condução do elenchos, desenvolvendo um raciocínio em tudo semelhante ao do Laques (192c-193e; do qual resultará a definição de Nícias - 194e-195a -, quase idêntica à adiante apresentada: Prt. 360d). Mas Protágoras não cai no erro de Laques e distingue «corajoso» de «destemido» (tharraleos: 350b; só o corajoso é virtuoso, o destemido limita-se a não ter medo).

Sócrates tenta então refutar Protágoras forçando a equivalência de «os corajosos são destemidos» (349e) a "Os destemidos são corajosos» (350bc), mas o sofista detecta a manobra (350c-351b). Sócrates deixa aparentemente cair a questão, optando por explorar outra equivalência: agora entre «agradável» e «bom» 351c sqq). Mas de novo Protágoras se mostra cauteloso, distinguindo o prazer do bom (351e sqq). 
É altura de Sócrates lançar novo argumento, que inicia questionando o sofista sobre o «saber» (epistêmê: 352b passim; a tradução parece-me melhor que «conhecimento», pelas razões aduzidas a seguir). Perante o respeito manifestado pelo sofista, Sócrates ensaia a redução ao absurdo da equivalência entre «bom» e «prazer». Mas o argumento requer a maior atenção.

Todos aqueles que, "sabendo o que é melhor», confessam serem "obrigados a fazer o que fazem, dominados pelo prazer [...]» (352d) e dessa forma exprimem a sua impotência (akrasia), mais não são que ignorantes. Pois só a ignorância explica que alguém deseje o que é mau (357b-e). Vale a pena aprofundar.

Como se explica que, identificando o bom com o prazer e o mau com a dor, alguém prefira um prazer que se vem a revelar mau? Ou que, pelo contrário, se entregue a um trabalho penoso, esperando do esforço vir a colher benefício? Só pode ser por ter medido prazer e dor, bem e mal, preferindo ter o menos dos piores e o mais dos melhores (354c-e).

Portanto, quem ainda assim prefere o mal ao bem escolhe o mal (a dor), dominado pelo bem (prazer), o que parece absurdo (355c-d). E a única possibilidade de escapar ao absurdo será advogar uma preferência qualificada da maior quantidade de bem à menor de mal.

Mas tal opção implica uma «arte da medida» (metretikê technê: 356d, passim; parece-me melhor que "comedimento", termo dominado por conotações morais, ausentes do Grego), capaz de correctamente pesar prazeres e dores (355d-356e). Tal opção implica, porém, o respeito pelo saber - em tudo oposto à ideia do «domínio pelo prazer» - , bem como a correspondente equação de "deixar-se dominar» com a ignorância (357b-e; e de "ser senhor de si próprio» com a sabedoria: 358c).

Depois de conseguir a ampla concordância da parte dos circunstantes (358a-b), Sócrates reforça ainda a conclusão atingida com uma série de reflexões aparentemente inócuas, que igualmente concitam o acordo de todos (358b-e).

Retoma então debate com Protágoras, regressando à comparação da coragem com as outras virtudes (359a-b). Contrasta agora os comportamentos dos corajosos e dos cobardes, tentando discernir em que se distinguem. Conclui que a diferença se acha na circunstância de uns buscarem as situações "que não atemorizam», enquanto os outros se entregam às que «causam temor» (359c).

Protágoras, porém, nota que essa hipótese («as coisas que causam temor são tidas como más»: 358e) foi afastada. E Sócrates concorda, acrescentando ainda que «ser dominado por si próprio revelou-se ser ignorância» (359d). Dessa impossibilidade resulta, contudo, que cobardes e corajosos sigam as mesmas coisas (359d-e). 
Protágoras nega de novo, explicando que, por exemplo, enquanto uns querem ir à guerra, os outros não (359e). Mas Sócrates aproveita para perguntar: se a guerra é louvável - logo boa -, portanto, agradável, por que razão quererão os corajosos participar nela e os cobardes não?

Não pode ser por uns terem medo e os outro não, já que os corajosos também têm medos (se não tivessem, seriam insensatos: hipótese do Laques). Acontece que não são censurados nem pelo que temem, nem pelo que não temem (360a-b), enquanto, pelo contrário, cobardes, destemidos e loucos são sempre censurados: os primeiros pelo medo que têm, os outros, pelo destemor (360b).

Ora qual poderá ser, em todos estes casos, a única explicação para o comportamento dos corajosos, cobardes e loucos? Ela só pode residir na ignorância (360c)! Daqui resulta ser a cobardia a ignorância das coisas temíveis e não temíveis (360c) e a coragem a sabedoria delas (360d). Fica assim concluído este extraordinário elenchos, que atinge o seu termo de forma tão inesperada, quão confusa.

Valerá então a pena recapitular o caminho feito ao longo do diálogo. A questão em debate, lembremo-la, é (1, acima) a do ensino da virtude (e da capacidade de Protágoras para o fazer). Com o primeiro argumento (2), Sócrates leva o sofista a recusar a unidade da virtude (viu-se que não poderia aceitá-la). Com o segundo e terceiro argumentos $(3,4)$, ficam estabelecidas as relações de identidade e contrariedade entre as virtudes e os correspondentes vícios. Passada a digressão (5), Protágoras é levado a distinguir a coragem das outras virtudes (6: consequência de 2). $\mathrm{O}$ argumento sobre a impotência (7) visa fornecer duas teses capitais para a refutação: a) "deixar-se vencer» é ignorância; b) ninguém que saiba prefere coisas más. A comparação da coragem com a cobardia (8) opera a refutação: como o cobarde se deixa vencer pelo medo (e o destemido e o louco pela insensatez: 350b, 360b; anulando o contra-exemplo de Protágoras: 349d, 359b), a cobardia só pode ser ignorância, logo, a coragem será sabedoria.

Que resulta da refutação? A derrota de Protágoras, apenas? Não, mais do que isso, a prova da sua incapacidade para ensinar a virtude. O que é extraordinário é que este resultado seja atingido pela demonstração da ensinabilidade da virtude, resultante do facto de ser saber! Esta é, portanto, a única razão para a inversão das posições iniciais dos dois contendores (9): agora o sofista nega que a virtude seja ensinável e o filósofo afirma-o. Inversão que, note-se, constitui a prova indirecta da «armação» do elenchos. Concluo assim a análise do argumento do diálogo, passando à apreciação do trabalho de tradução, apresentação e comentário da obra.

2. Como salientei atrás, este trabalho parece-me muito satisfatório não só pela seriedade e rigor da tradução, mas também pelo grande cuidado posto na apresentação da obra, expresso na qualidade da introdução, no porme- 
nor, pertinência e extensão das notas, bem como na actualizada bibliografia. A introdução poderia ter incluído uma análise das dificuldades filosóficas postas pelo diálogo, mas não me parece que se deva considerar essencial essa tarefa. No sentido de contribuir para um melhoramento nas futuras edições, apresento, para além dos reparos feitos atrás, algumas críticas, notando erros e gralhas e fazendo sugestões. Começo pelas últimas.

Qualquer tradução de epistêmê põe problemas. Neste diálogo até nem põe muitos, por só haver duas alternativas: "conhecimento» e «saber». A tradutora preferiu a primeira, pessoalmente, opto pela segunda. Por diversas razões. A epistêmê é um estado - o saber -; entre ela e o seu oposto, a agnoia, ou amathia - a ignorância —, não é possível o trânsito.

Pelo contrário, o conhecimento é um processo, que relaciona duas entidades distintas: um sujeito e um objecto. Todavia, como nem o homem é um sujeito, nem a virtude um objecto, a sua relevância no Protágoras é nula. Não há nada para conhecer na virtude. Se houvesse, todos seríamos virtuosos na medida dos conhecimentos que possuímos. Mas não somos.

Pelo contrário, a hipótese a «virtude é saber» $(M$. 87c) é a única que pode conferir sentido ao projecto levado a cabo nos «diálogos sobre a virtude». Projecto, no qual o Protágoras se insere e desempenha uma função capital: a de evidenciar as aporias da ensinabilidade da virtude (que só o ensino «filosófico» superará: como demonstra o Ménon). Ora, toda esta riqueza de relações temáticas desaparece, ou é obscurecida pela tradução «conhecimento».

Por outro lado, o termo tem para nós um sentido que reflecte dois milénios de reflexão contínua e patenteia uma problemática hoje perfeitamente definida. Afectá-la às questões tratadas no Protágoras é fazer de Platão um pensador estranho a si mesmo.

Posto isto, o problema pode resolver-se de duas maneiras: uma, drástica, alterando a tradução. Outra, mais leve e descomprometedora, resolvendo a questão com uma nota (aproveitando a circunstância de a tradução não se poder considerar errada!).

E passo aos erros. Falar da «unicidade da virtude» é errado. Em primeiro lugar, porque o texto fala sempre de «unidade» («hen»; vide, tauta hôs hen ti eiê syllêbdên: 329c, passim). Por outro lado, do ponto de vista lógico e filosófico, falar de unicidade é suprimir a ambiguidade entre as várias leituras da tese da unidade das virtudes: «unidade», "semelhança», e «bicondicional» (G. Vastos, "The Unity of the Virtues in The Protagoras», in Platonic Studies, Princeton, 1973, 221-269, 427-445). Não é de uma «única» que se fala, mas de «uma»: unitária, funcionalmente diversificada, ou uma e outra simultaneamente.

Quanto a erros da tradução, notei dois: 
RECENSÕES

«Porque ninguém castiga, por praticar injustiças, aqueles que as praticam sem noção do que fazem» (324a-b: p. 95, Is. 3-4).

À letra seria:

«Porque ninguém que tenha juízo (ton noun echôn) castiga quem comete injustiça, por isso mesmo e por causa disso, porque cometeu injustiça...»

Em causa está o texto traduzido em itálico, que confere à tese um sentido a ela de todo alheio. A dificuldade vem da expressão «ton noun echôn», que só pode ser aposta a «ninguém», e não corresponde à tradução apresentada. Ora é essencial não pensar que Protágoras está a desculpar os «involuntariamente injustos». A sua tese é mais generosa e ousada (e também polémica!): toda a punição deve ter um fim preventivo.

O outro erro é:

«... a justiça, é algo justo ou injusto?» (330c; p. 102, últ. linha))

Esta é a famosa tese da auto-predicação. A melhor tradução é a mais simples:

«... a justiça, é ela própria justa ou injusta?»

Donde, mais adiante:

«... a justiça é semelhante ao ser-se justo».

É simplificar a ponto de dissolver a questão. Não há qualquer indício de personalização da justiça. É da Forma da justiça que se está a falar, e para sustentar que:

«... a justiça é tal (toiouton) qual (hoion) ser justo».

Ou, numa tradução «mais filosófica»:

«... a justiça é do género [do] justo».

Já as gralhas são várias.

«... será também uma arte de conhecimento» (357b: p. 141, I. 6)

Aqui não há outra tradução: 
RECENSÕES

«... será também arte e saber» (ou «conhecimento»).

Outra:

«se chamaria corajosos aos destemidos» (359b-c: p. 144, Is. 5-6)

O que está no texto é:

«Se chamaria aos corajosos destemidos».

Sem esta correcção o argumento torna-se de todo incompreensível (vide $349 e, 350 c-d)$.

«der louvável» (130, I. 19), em vez de «ser louvável».

E, por fim:

«infringido» $(161$, I. 2), em vez de «infligido».

José Trindade Santos

Departamento de Filosofia

Faculdade de Letras da Universidade de Lisboa

Alameda da Universidade, 1600-214 Lisboa

trindad@mail.telepac.pt 